\title{
An active nitrogen cycle on Mars sufficient to support a subsurface biosphere
}

\author{
C.S. Boxe', K.P. Hand', K.H. Nealson ${ }^{2}$, Y.L. Yung ${ }^{3}$ and A. Saiz-Lopez ${ }^{1,4}$ \\ ${ }^{1}$ Earth and Space Science Division, Jet Propulsion Laboratory, California Institute of Technology, Pasadena, CA 91109 , \\ USA \\ e-mail: boxeman3@gmail.com \\ ${ }^{2}$ Department of Earth Sciences, University of Southern California, Los Angeles, CA 90089, USA \\ ${ }^{3}$ Division of Geological and Planetary Sciences, California Institute of Technology, 1200 East California Boulevard, \\ Pasadena, CA 91125, USA \\ ${ }^{4}$ Laboratory for Atmospheric and Climate Sciences, CSIC, Toledo, Spain
}

\begin{abstract}
Mars' total atmospheric nitrogen content is 0.2 mbar. One-dimensional (1D) photochemical simulations of Mars' atmosphere show that nitric acid $\left(\mathrm{HNO}_{3}(\mathrm{~g})\right)$, the most soluble nitrogen oxide, is the principal reservoir species for nitrogen in its lower atmosphere, which amounts to a steady-state value of $6 \times 10^{-2} \mathrm{~kg}$ or 4 moles, conditions of severe nitrogen deficiency. Mars could, however, support $\sim 10^{15} \mathrm{~kg}$ of biomass $\left(\sim 1 \mathrm{~kg} \mathrm{~N} \mathrm{~m}^{-2}\right)$ from its current atmospheric nitrogen inventory. The terrestrial mass ratio of nitrogen in biomass to that in the atmosphere is $\sim 10^{-5}$; applying this ratio to Mars yields $\sim 10^{10} \mathrm{~kg}$ of total biomass - also, conditions of severe nitrogen deficiency. These amounts, however, are lower limits as the maximum surface-sink of atmospheric nitrogen is $2.8 \mathrm{mbar}\left(9 \times 10^{15} \mathrm{~kg}\right.$ of $\left.\mathrm{N}\right)$, which indicates, in contradistinction to the Klingler et al. (1989), that biological metabolism would not be inhibited in the subsurface of Mars. Within this context, we explore $\mathrm{HNO}_{3}$ deposition on Mars' surface (i.e. soil and icecovered regions) on pure water metastable thin liquid films. We show for the first time that the negative change in Gibbs free energy increases with decreasing $\mathrm{HNO}_{3}(\mathrm{~g})\left(\mathrm{NO}_{3}{ }^{-}(\mathrm{aq})\right)$ in metastable thin liquid films that may exist on Mars' surface. We also show that additional reaction pathways are exergonic and may proceed spontaneously, thus providing an ample source of energy for nitrogen fixation on Mars. Lastly, we explore the dissociation of $\mathrm{HNO}_{3}(\mathrm{~g})$ to form $\mathrm{NO}_{3}{ }^{-}(\mathrm{aq})$ in metastable thin liquid films on the Martian surface via condensed phase simulations. These simulations show that photochemically produced fixed nitrogen species are not only released from the Martian surface to the gas-phase, but more importantly, transported to lower depths from the Martian surface in transient thin liquid films. A putative biotic layer at $10 \mathrm{~m}$ depth would produce $\mathrm{HNO}_{3}$ and $\mathrm{N}_{2}$ sinks of -54 and $-5 \times 10^{12}$ molecules $\mathrm{cm}^{-2} \mathrm{~s}^{-1}$, respectively, which is an ample supply of available nitrogen that can be efficiently transported to the subsurface. The downward transport as well as the release to the atmosphere of photochemically produced fixed nitrogen species (e.g. $\mathrm{NO}_{2}{ }^{-}, \mathrm{NO}$ and $\mathrm{NO}_{2}$ ) suggests the existence of a transient but active nitrogen cycle on Mars.
\end{abstract}

Received 23 March 2011, accepted 4 December 2011, first published online 16 January 2012

Key words: Mars, nitrogen, nitrogen fixation, klingler hypothesis, free energy.

\section{Introduction}

Dinitrogen $\left(\mathrm{N}_{2}\right)$ comprises $2.7 \%$ of the Martian atmosphere, which is equivalent to a total atmospheric mass of $\sim 10^{15} \mathrm{~kg}$. Still, to date, there has been no direct and thorough analysis of the nitrogen content of the Martian lithosphere. Consequently, the total inventory of nitrogen for the planet is unknown (Mancinelli \& Banin 2003; Summers \& Khare 2007), which contributes to the degree of uncertainty pertaining to the amount of nitrogen lost to space compared to the amount deposited on its surface and sequestered at its subsurface. It may be possible, though, that both processes have taken place concurrently and are ongoing (Mancinelli \& Banin 2003; Summers \& Khare 2007). Moreover, the isotope ratio enhancement of atmospheric nitrogen on Mars compared to Earth $\left({ }^{15} \mathrm{~N} /{ }^{14} \mathrm{~N}(\right.$ Mars $) /{ }^{15} \mathrm{~N} /{ }^{14} \mathrm{~N}$ (Earth) $\left.\sim 1.6\right)$ is used as evidence for significant nitrogen loss but not the total amount lost to space (Jakosky \& Phillips 2001).

Thin liquid films on the surface and subsurface (i.e. tens of centimetres to $1 \mathrm{~m}$ depth) of Mars may range from 0.2 to $5 \mathrm{~nm}$ and $\sim 1 \mathrm{~nm}$, respectively (Boxe et al. submitted). Although the diameter of bacteria, archaea and eukarya range from $\sim 0.40 \mu \mathrm{m}$ to several microns (Huber et al. 2002; Price 2007), biological activity on Martian surface or subsurface may not be limited by the nanometre dimensions of such thin liquid films (Price 2007). As nitrogen is an essential biochemical element, we discuss the implications for nitrogen fixation on Mars due to the existence of such films. We calculate upper and lower limits for Martian steady-state biomass by assuming the abundance of gas-phase nitrogen to be the limiting factor for biomass production. We also consider a nitrogen cycle facilitated by nitric acid $\left(\mathrm{HNO}_{3}(\mathrm{~g})\right)$ dissolution and subsequent 
heterogeneous photochemistry in thin films of metastable liquid water that may exist on the surface and subsurface of Mars; the heterogeneous photochemistry of nitrate $\left(\mathrm{NO}_{3}{ }^{-}\right)$ produces $\mathrm{NO}, \mathrm{NO}_{2}$ and $\mathrm{NO}_{2}{ }^{-}$species that can either diffuse to Mars' atmosphere or transported downward through Mars' subsurface. This cycle involves exothermic reactions that provide ample amounts of energy that can be then used for biosynthesis (e.g. nitrogen fixation) (Rubio \& Ludden 2005; Zehr et al. 2005; Ducluzeau et al. 2009). This allows for a quantitative comparison between using solely atmospheric nitrogen as a nutrient source and the maximum amount of subsurface nitrogen. Within this context, we also quantitatively assess the limiting factors for nitrogen fixation on Mars (e.g. available nitrogen, energy and water).

\section{Results and discussion}

\section{Contradistinction to the Klingler hypothesis}

Model estimates indicate that impacts, hydrodynamic escape and sputtering removed $99 \%$ of the Mars's initial atmosphere (McElroy et al. 1977; Bogard et al. 2001). Earth scaling and models estimated an initial nitrogen atmospheric inventory ranging from 2 to $300 \mathrm{mbar}$ (McKay \& Stoker 1989), providing, at most, over three orders of magnitude more nitrogen for a primordial Martian biosphere. Taking into account Mars' current atmospheric nitrogen content (i.e. $0.2 \mathrm{mbar}$ ), this yields a maximum nitrogen missing sink of $2.8 \mathrm{mbar}$ $\left(9 \times 10^{15} \mathrm{~kg}\right.$ of $\left.\mathrm{N}\right)$. A maximum nitrogen missing sink of $2.8 \mathrm{mbar}$ is plausible as atmospheric nitrogen would accumulate over millennial time frames in the near-surface (i.e. top few metres) as water infiltration and leaching are minimal (Walvoord et al. 2003; Graham et al. 2008). Were the current entire atmospheric reservoir to be converted into biomass, Mars could at most support $\sim 10^{15} \mathrm{~kg}$ of biomass, or roughly $1 \mathrm{~kg} \mathrm{~m}^{-2}$ over the surface. By comparison, primary productivity (photosynthetic) on Earth is $\sim 10^{14} \mathrm{~kg} \mathrm{yr}^{-1}$ (Field et al. 1998). The terrestrial mass ratio of nitrogen in biomass to that in the atmosphere is $\sim 10^{-5}$ (Capone et al. 2006); if this ratio were to hold for Mars, we might expect $\sim 10^{10} \mathrm{~kg}$ of total biomass. Therefore, micro-organism growth could clearly not be supported if the only nitrogen source were from the atmosphere. However, if the $9 \times 10^{15} \mathrm{~kg}$ of subsurface $\mathrm{N}$ were added to the mix, then biological processes could still be occurring (Klingler et al. 1989). If just $10 \%$ of the atmospheric nitrogen lost between early Mars and contemporary Mars went into abiotic or biogenic sediments, from an initial nitrogen inventory of 18 mbar (Fox \& Delgarno 1983; Klingler et al. 1989), then $\sim 10^{11} \mathrm{~kg}$ should be expected in the Martian rock record, comparable to the nitrogen sequestered in sediments on Earth, $\sim 10^{11} \mathrm{~kg}$ (Field et al. 1998).

Activity on the Martian surface is limited to diffusion and heterogeneous photochemical processes. Lateral dissolution of atmospheric species would occur in thin liquid films with thicknesses ranging from $\sim 1$ to $6 \mathrm{~nm}$ given atomic diameters are $\sim 1$ to a few angstroms. Therefore, lateral dissolution of $\mathrm{HNO}_{3}$ would occur at Mars' surface. 1D gas-phase

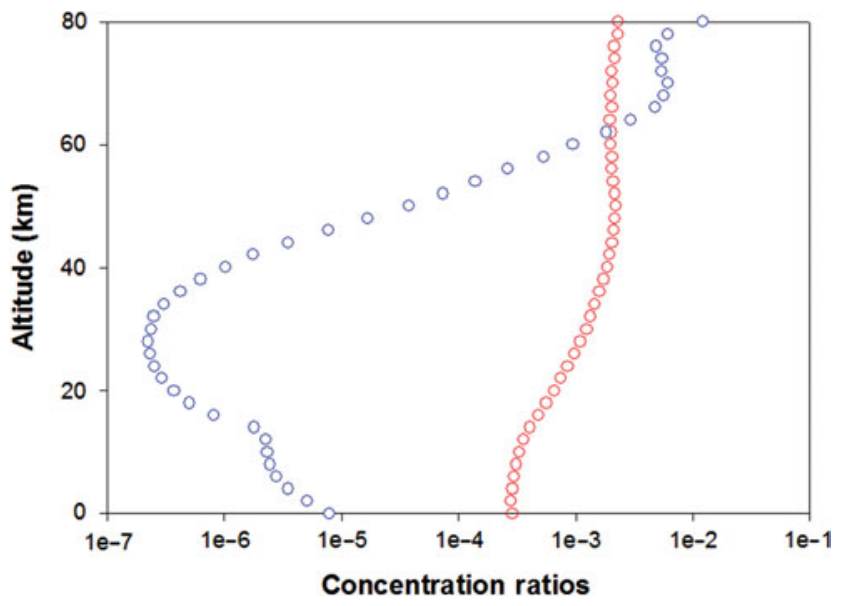

Fig. 1. 1D model simulation of altitude $(\mathrm{km})$ versus $\left[\mathrm{HNO}_{3}(\mathrm{~g})\right]_{\text {Mars }} /$ $\left[\mathrm{HNO}_{3}(\mathrm{~g})\right]_{\text {Earth }}$ and $\left[\mathrm{N}_{2}(\mathrm{~g})\right]_{\text {Mars }} /\left[\mathrm{N}_{2}(\mathrm{~g})\right]_{\text {Earth }}$.

photochemical simulations, constrained by Viking NO measurements, made in the upper Martian atmosphere, show that $\mathrm{HNO}_{3}$ is one of the principal reservoir species for nitrogen in its lower atmosphere, representing $\sim 10^{-11}$ of Mars' current total nitrogen content. The Henry's law coefficients of other nitrogen oxides' are orders of magnitude smaller than $\mathrm{HNO}_{3}$. For instance, the Henry's law coefficient for $\mathrm{N}_{2}, \mathrm{NO}, \mathrm{NO}_{2}$, $\mathrm{N}_{2} \mathrm{O}, \mathrm{HNO}_{2}$ and $\mathrm{HNO}_{3}$ are $6 \times 10^{-4}, 2 \times 10^{-3}, 1 \times 10^{-2}$, $3 \times 10^{-2}, 49$ and $2 \times 10^{5} \mathrm{M} \mathrm{atm}^{-1}$, respectively. Therefore, the dissolution of gas-phase $\mathrm{HNO}_{3}$ is extremely efficient. 1D photochemical simulations show that the current steady-state concentration of $\mathrm{HNO}_{3}(\mathrm{~g})$ just above the Martian surface is $\sim 5 \times 10^{5}$ molec. $\mathrm{cm}^{-3}\left(8 \times 10^{-16} \mathrm{M}\right.$ of $\left.\mathrm{NO}_{3}{ }^{-}\right)$, which represents $\sim 10^{-11} \%$ of the total atmospheric nitrogen content, just above the Martian surface. Given that the total amount of thin liquid film ranges from $3.5 \times 10^{6}$ to $2 \times 10^{7}$ litres, $2 \times 10^{-9}$ moles $\left(1.5 \times 10^{-10} \mathrm{~kg}\right)$ to $2 \times 10^{-7}$ moles $\left(1.5 \times 10^{-8} \mathrm{~kg}\right)$ of $\mathrm{NO}_{3}{ }^{-}$is available at the Martian surface. Dissolution of $\mathrm{N}_{2}$ may also occur on slower timescales as its Henry's law constant is $6 \times 10^{-4} \mathrm{M} \mathrm{atm}^{-1}$. The current steady-state concentration of $\mathrm{N}_{2}(\mathrm{~g})$ just above the Martian surface is $\sim 5 \times 10^{15}$ molec. $\mathrm{cm}^{-3}$ $\left(9.6 \times 10^{-6} \mathrm{M} \mathrm{N}_{2}\right)$, which equates to $\sim 10^{-6} \%$ of the total atmospheric nitrogen content and $\sim 30$ moles $(1 \mathrm{~kg}$ ) to $\sim 3000$ moles $(80 \mathrm{~kg})$ of $\mathrm{N}_{2}$ (i.e. the amount of $\mathrm{N}_{2}$ that would be available at the Martian surface). Within these contexts, potential life would have to thrive under conditions of severe nitrogen deficiency as $\left[\mathrm{HNO}_{3}\right]$ and $\left[\mathrm{N}_{2}\right]$ in the Martian atmosphere is a small fraction of their respective amounts in Earth's atmosphere (e.g. $\sim 10^{-5}$ to 0.03 , respectively, at the surface, Fig. 1).

\section{Exothermic reactions as a source of energy for nitrogen fixation}

Weiss et al. (2000) showed that subsurface Martian organisms could be supplied with a large energy flux from the oxidation of photochemically produced atmospheric $\mathrm{H}_{2}$ and $\mathrm{CO}$ diffusing into the regolith. Surface abundance measurements of these gases demonstrate that not more than a few percent of this 
available flux is actually consumed, suggesting that biological activity driven by $\mathrm{H}_{2}$ and $\mathrm{CO}$ is limited in the top few hundred metres of the subsurface, far exceeding the energy derivable from other atmospheric gases. They show for organisms at $30 \mathrm{~m}$ depth that the hydrothermal and chemical weathering energy is 2000 times more than previous estimates. This implies that the apparent scarcity of life on Mars is not attributable to lack of energy. The following thermodynamic calculations support this notion as exothermic reactions may occur on thin liquid films to release energy for nitrogen fixation.

Nitrogen is linked by a very strong triple bond and is energetically expensive (bond strength $\sim 945 \mathrm{~kJ} \mathrm{~mole}^{-1}$ - see reactions (1) and (2)). Fixed nitrogen (i.e. $\mathrm{NH}_{3}, \mathrm{NH}_{4}{ }^{+}$and $\mathrm{NO}_{x}$ or nitrogen that is chemically bound to either inorganic or organic molecules that can be released by hydrolysis to form $\mathrm{NH}_{3}$ and $\mathrm{NH}_{4}{ }^{+}$) is useful to living organisms (Ducluzeau et al. 2009). Available quantities of free energy are crucial for supporting life and debated in terms of it being a requirement for nitrogen fixation:

$\mathrm{N}_{2(\mathrm{~g})}+6 \mathrm{H}^{+}+6 \mathrm{e}^{-}+$energy $\rightarrow 2 \mathrm{NH}_{3}$.

$\mathrm{N}_{2(\mathrm{~g})}+8 \mathrm{H}^{+}+8 \mathrm{e}^{-}+$energy $\rightarrow 2 \mathrm{NH}_{3}+\mathrm{H}_{2}$.

For chemical reactions, we are often interested in the change in Gibbs free energy $(\Delta G)$,

$\Delta G=\Delta G^{o}+R T \ln \left(\frac{\left(P_{C}\right)^{m}\left(P_{D}\right)^{n}}{\left(P_{A}\right)^{x}\left(P_{B}\right)^{y}}\right)=\Delta G^{o}+R T \ln (Q)$,

where $P$ is the pressure, $T$ is the temperature, $R$ is the universal gas constant, $Q$ is the reaction quotient, $A, B, C$ and $D$ are reactants, respectively, $m, n, x$ and $y$ are coefficients of reactants, and products $\Delta G^{o}$ is the standard free energy change (at 1 bar and $25^{\circ} \mathrm{C}$ ). The standard free energies for nitrogen, oxygen, water and nitric acid in the following reaction

$\frac{1}{2} \mathrm{~N}_{2(\mathrm{~g})}+\frac{5}{4} \mathrm{O}_{2(\mathrm{~g})}+\frac{1}{2} \mathrm{H}_{2} \mathrm{O}_{(\mathrm{l})} \Leftrightarrow \mathrm{HNO}_{3(\mathrm{aq})}$

are, respectively $0,0,-236.65$ and $-110.88 \mathrm{~kJ} \mathrm{~mole}^{-1}$, yielding $\Delta G^{o}=7.45 \mathrm{~kJ} \mathrm{~mole}^{-1}$. This reaction, requiring a positive change in Gibbs free energy, is not spontaneous and will proceed only with the addition of energy. We can now calculate conditions when the above reaction will proceed without the addition of free energy. Given Mars's mean atmospheric surface pressure of $5.53 \times 10^{-3} \mathrm{~atm}$ (or $5.6 \mathrm{mbar}$ ), its $\mathrm{N}_{2}(\mathrm{~g}$ ) and $\mathrm{O}_{2}(\mathrm{~g})$ abundances are $2.7 \%$ and $0.13 \%$, respectively, we approximate $\mathrm{N}_{2}(\mathrm{~g})$ and $\mathrm{O}_{2}(\mathrm{~g})$ pressures to be $1.49 \times 10^{-4}$ and $7.19 \times 10^{-6} \mathrm{~atm}$, respectively. We assume here that water in the form of thin liquid films had unit activity. So, at equilibrium:

$\Delta G=0$,

$\Delta G^{o}=-R T \log (Q)=-5.71 \log (Q)$,

$\log (Q)=\log \left(\frac{a_{\mathrm{HNO}_{3}(\mathrm{aq})}}{a_{\mathrm{N}_{2}}^{1 / 2} a_{\mathrm{O}_{2}}^{5 / 4}}\right)=-\frac{7.45}{5.71}=-1.304$

Or $Q=0.0497$,

$a_{\mathrm{HNO}_{3(\mathrm{aq})}}=Q \times\left(1.4 \times 10^{-4}\right)^{1 / 2} \times\left(7.19 \times 10^{-6}\right)^{5 / 4}$ $=2.00 \times 10^{-10}$,
This value corresponds to a concentration of $\sim 3 \mathrm{~nm}$ (Lide 2006). So, as long as $\left[\mathrm{HNO}_{3}\right.$ (aq.) or $\left.\mathrm{NO}_{3}{ }^{-}\right]$remains below $\sim 3 \mathrm{~nm}$, reaction (2) will proceed with the liberation of free energy.

Given the fact that $\left[\mathrm{HNO}_{3}\right.$ (aq.) or $\left.\mathrm{NO}_{3}{ }^{-}\right]$is likely smaller than $\sim 3 \mathrm{~nm}$ (e.g. $8 \times 10^{-16} \mathrm{M}$ of steady-state $\mathrm{HNO}_{3}$ by $1 \mathrm{D}$ photochemical simulations) there is heat (not work) liberated for partial use as chemical energy. The more dilute the concentration at which nitrate is formed, the greater the amount of available work (not heat) will be available. If we assume that $\left[\mathrm{HNO}_{3}\right]$ ranges from $10^{-16}$ to $10^{-9} \mathrm{M}$ and the activity coefficient at this concentration is unity, the following calculations show that the free energy is

$$
\begin{aligned}
& Q=\frac{\left(10^{-9}\right)}{\left(1.4 \times 10^{-4}\right)^{1 / 2} \times\left(7.19 \times 10^{-6}\right)^{5 / 4}}=0.36, \\
& Q=\frac{\left(10^{-16}\right)}{\left(1.4 \times 10^{-4}\right)^{1 / 2} \times\left(7.19 \times 10^{-6}\right)^{5 / 4}}=3.61 \times 10^{-8} .
\end{aligned}
$$

Then

$$
\begin{aligned}
\Delta G & =\Delta G^{o}+R T \log (Q)=7.45+5.71(-0.44) \\
& =4.92 \mathrm{~kJ} \mathrm{~mole}^{-1} \text { and } \Delta G=7.45+5.71(-7.44) \\
& =-35.05 \mathrm{~kJ} \mathrm{~mole}^{-1} .
\end{aligned}
$$

These calculations show that the negative change in Gibbs free energy increases with decreasing $\mathrm{HNO}_{3}$. In other words, for the low concentration of $\mathrm{HNO}_{3}$ (in the form of $\mathrm{NO}_{3}{ }^{-}$), we expect for pure water thin liquid films on the surface of Mars, reaction (2) is exergonic and may proceed spontaneously. Figure 2 exemplifies the relationship between the change in Gibbs free energy and $\mathrm{HNO}_{3}$ concentration. Temperatures shown correspond to the 186, 227 and $268 \mathrm{~K}$. For the warmest temperature, $\mathrm{HNO}_{3}$ concentrations of $<10^{-9} \mathrm{M}$ yield a negative change in Gibbs free energy. At $186 \mathrm{~K}$, concentrations of $<3 \times 10^{-11} \mathrm{M}$ yield a negative change in Gibbs free energy. At the mean surface temperature of Mars $(227 \mathrm{~K})$, an $\mathrm{HNO}_{3}$ concentration of $8 \times 10^{-11} \mathrm{M}$ or less yields a negative change in Gibbs free energy.

The foregoing analyses fail to serve for anaerobic organisms, such as Clostridium, which can fix nitrogen in the absence of oxygen. The production of aqueous ammonia from nitrogen and hydrogen is attended by $\Delta G^{o}=-26$ and $\Delta H^{o}=-84.84 \mathrm{~kJ} \mathrm{~mole}^{-1}$ (reaction 4 ).

$\frac{1}{2} \mathrm{~N}_{2(\mathrm{~g})}+\frac{3}{2} \mathrm{H}_{2(\mathrm{~g})}+\mathrm{H}_{2} \mathrm{O}_{(\mathrm{l})} \Leftrightarrow \mathrm{NH}_{4} \mathrm{OH}_{4(\mathrm{aq})}$.

In comparison, if oxygen were present (reaction 11), replacing water (reaction 11), $\Delta G^{o}=-263.01 \mathrm{~kJ}^{\text {mole }}{ }^{-1}$.

$\frac{1}{2} \mathrm{~N}_{2(\mathrm{~g})}+\frac{5}{2} \mathrm{H}_{2(\mathrm{~g})}+\frac{1}{2} \mathrm{O}_{2(\mathrm{~g})} \Leftrightarrow \mathrm{NH}_{4} \mathrm{OH}_{4(\mathrm{aq})}$.

An analogous assessment can be made between reactions (2) and (12), where $\Delta G^{o}=-110.88$ and $\Delta H^{o}=-205.44 \mathrm{~kJ} \mathrm{~mole}^{-1}$ in reaction (12) due to the presence of hydrogen

$\frac{1}{2} \mathrm{~N}_{2(\mathrm{~g})}+\frac{1}{2} \mathrm{H}_{2(\mathrm{~g})}+\frac{3}{2} \mathrm{O}_{2(\mathrm{~g})} \Leftrightarrow \mathrm{HNO}_{3(\mathrm{aq})}$. 
Table 1. Interfacial film reactions and rate constants

\begin{tabular}{|c|c|c|}
\hline Reactions & Aqueous rate constants ${ }^{\mathrm{a}}$ & QLL rate constants ${ }^{\mathrm{b}}$ \\
\hline $\mathrm{NO}_{3}^{-}+h v \rightarrow \mathrm{NO}_{2}+\mathrm{O}^{-}$ & & c \\
\hline $\left.\mathrm{NO}_{3}^{-}+h v \rightarrow \mathrm{NO}_{2}^{-}+\mathrm{O}^{3} \mathrm{P}\right)$ & & $\mathrm{c}$ \\
\hline $\mathrm{NO}_{2}^{-}+h v \rightarrow \mathrm{NO}+\mathrm{O}^{-}$ & & d \\
\hline $\mathrm{O}^{-}+\mathrm{H}_{2} \mathrm{O} \rightarrow . \mathrm{OH}+\mathrm{OH}^{-}$ & $2.82 \times 10^{-15} \mathrm{~cm}^{3} \mathrm{molec}^{-1} \mathrm{~s}^{-1}$ & $2.82 \times 10^{-15} \mathrm{~cm}^{3} \mathrm{molec}^{-1} \mathrm{~s}^{-1} /(\text { volumetric })^{\mathrm{e}}$ \\
\hline $\mathrm{OH}+\mathrm{OH}^{-} \rightarrow \mathrm{O}^{-}+\mathrm{H}_{2} \mathrm{O}$ & $2.00 \times 10^{-11} \mathrm{~cm}^{3} \mathrm{molec}^{-1} \mathrm{~s}^{-1}$ & $2.00 \times 10^{-11} \mathrm{~cm}^{3} \mathrm{molec}^{-1} \mathrm{~s}^{-1} /(\text { volumetric })^{\mathrm{e}}$ \\
\hline $\mathrm{O}_{2}+\mathrm{O}\left({ }^{3} \mathrm{P}\right) \rightarrow \mathrm{O}_{3}$ & $6.64 \times 10^{-12} \mathrm{~cm}^{3} \mathrm{molec}^{-1} \mathrm{~s}^{-1}$ & $6.64 \times 10^{-12} \mathrm{~cm}^{3} \mathrm{molec}^{-1} \mathrm{~s}^{-1} /(\text { volumetric })^{\mathrm{e}}$ \\
\hline $\mathrm{O}\left({ }^{3} \mathrm{P}\right)+\mathrm{NO}_{2}^{-} \rightarrow \mathrm{NO}_{3}^{-}$ & $2.46 \times 10^{-12} \mathrm{~cm}^{3} \mathrm{molec}^{-1} \mathrm{~s}^{-1}$ & $2.46 \times 10^{-12} \mathrm{~cm}^{3} \mathrm{molec}^{-1} \mathrm{~s}^{-1} /(\text { volumetric })^{\mathrm{e}}$ \\
\hline $\mathrm{O}_{3}+\mathrm{NO}_{2}^{-} \rightarrow \mathrm{NO}_{3}^{-}+\mathrm{O}_{2}$ & $6.15 \times 10^{-16} \mathrm{~cm}^{3} \mathrm{molec}^{-1} \mathrm{~s}^{-1}$ & $6.15 \times 10^{-16} \mathrm{~cm}^{3} \mathrm{molec}^{-1} \mathrm{~s}^{-1} /(\text { volumetric })^{\mathrm{e}}$ \\
\hline $\mathrm{NO}_{3}{ }^{-}+\mathrm{O}\left({ }^{3} \mathrm{P}\right) \rightarrow \mathrm{NO}_{2}{ }^{-}+\mathrm{O}_{2}$ & $3.72 \times 10^{-13} \mathrm{~cm}^{3} \mathrm{molec}^{-1} \mathrm{~s}^{-1}$ & $3.72 \times 10^{-13} \mathrm{~cm}^{3} \mathrm{molec}^{-1} \mathrm{~s}^{-1} /(\text { volumetric })^{\mathrm{e}}$ \\
\hline $\mathrm{NO}_{2}^{-}+. \mathrm{OH} \rightarrow \mathrm{NO}_{2}+\mathrm{OH}^{-}$ & $3.32 \times 10^{-11} \mathrm{~cm}^{3} \mathrm{molec}^{-1} \mathrm{~s}^{-1}$ & $3.32 \times 10^{-11} \mathrm{~cm}^{3} \mathrm{molec}^{-1} \mathrm{~s}^{-1} /(\text { volumetric })^{\mathrm{e}}$ \\
\hline $\mathrm{NO}_{2}+\mathrm{NO}_{2}+\mathrm{H}_{2} \mathrm{O} \rightarrow \mathrm{NO}_{2}^{-}+\mathrm{NO}_{3}^{-}+2 \mathrm{H}^{+}$ & $1.66 \times 10^{-13} \mathrm{~cm}^{3} \mathrm{molec}^{-1} \mathrm{~s}^{-1}$ & $1.66 \times 10^{-13} \mathrm{~cm}^{3} \mathrm{molec}^{-1} \mathrm{~s}^{-1} /(\text { volumetric })^{\mathrm{e}}$ \\
\hline $\mathrm{NO}+\mathrm{NO}_{2}+\mathrm{H}_{2} \mathrm{O} \rightarrow 2 \mathrm{NO}_{2}^{-}+2 \mathrm{H}^{+}$ & $3.32 \times 10^{-13} \mathrm{~cm}^{3} \mathrm{molec}^{-1} \mathrm{~s}^{-1}$ & $3.32 \times 10^{-13} \mathrm{~cm}^{3} \mathrm{molec}^{-1} \mathrm{~s}^{-1} /(\text { volumetric })^{\mathrm{e}}$ \\
\hline $\mathrm{NO}+. \mathrm{OH} \rightarrow \mathrm{NO}_{2}^{-}+\mathrm{H}^{+}$ & $3.32 \times 10^{-11} \mathrm{~cm}^{3}$ molec $^{-1} \mathrm{~s}^{-1}$ & $3.32 \times 10^{-11} \mathrm{~cm}^{3} \mathrm{molec}^{-1} \mathrm{~s}^{-1} /(\text { volumetric })^{\mathrm{e}}$ \\
\hline $\mathrm{NO}_{2}+. \mathrm{OH} \rightarrow \mathrm{NO}_{3}^{-}+\mathrm{H}^{+}$ & $2.16 \times 10^{-12} \mathrm{~cm}^{3} \mathrm{molec}^{-1} \mathrm{~s}^{-1}$ & $2.16 \times 10^{-12} \mathrm{~cm}^{3} \mathrm{molec}^{-1} \mathrm{~s}^{-1} /(\text { volumetric })^{\mathrm{e}}$ \\
\hline $\mathrm{NO}+\mathrm{NO}_{2} \rightarrow \rightarrow \mathrm{N}_{2} \mathrm{O}_{3}$ & $1.83 \times 10^{-12} \mathrm{~cm}^{3} \mathrm{molec}^{-1} \mathrm{~s}^{-1}$ & $1.83 \times 10^{-12} \mathrm{~cm}^{3} \mathrm{molec}^{-1} \mathrm{~s}^{-1} /(\text { volumetric })^{\mathrm{e}}$ \\
\hline $\mathrm{N}_{2} \mathrm{O}_{3}+\mathrm{H}_{2} \mathrm{O} \rightarrow 2 \mathrm{NO}_{2}^{-}+2 \mathrm{H}^{+}$ & $5.3 \times 10^{2} \mathrm{~s}^{-1}$ & $5.3 \times 10^{2} \mathrm{~s}^{-1}$ \\
\hline $2 \mathrm{NO}_{2} \rightarrow \mathrm{N}_{2} \mathrm{O}_{4}$ & $7.48 \times 10^{-13} \mathrm{~cm}^{3} \mathrm{molec}^{-1} \mathrm{~s}^{-1}$ & $7.48 \times 10^{-13} \mathrm{~cm}^{3} \mathrm{molec}^{-1} \mathrm{~s}^{-1} /(\text { volumetric })^{\mathrm{e}}$ \\
\hline $\mathrm{N}_{2} \mathrm{O}_{4}+\mathrm{H}_{2} \mathrm{O} \rightarrow \mathrm{NO}_{2}^{-}+\mathrm{NO}_{3}^{-}+2 \mathrm{H}^{+}$ & $10^{3} \mathrm{~s}^{-1}$ & $10^{3} \mathrm{~s}^{-1}$ \\
\hline $\mathrm{OH}+\mathrm{NO}_{2}^{-} \rightarrow \mathrm{HOONO}$ & $2.20 \times 10^{-12} \mathrm{~cm}^{3} \mathrm{molec}^{-1} \mathrm{~s}^{-1}$ & $2.20 \times 10^{-12} \mathrm{~cm}^{3} \mathrm{molec}^{-1} \mathrm{~s}^{-1} /(\text { volumetric })^{\mathrm{e}}$ \\
\hline $\mathrm{HOONO} \rightarrow \mathrm{NO}_{3}{ }^{-}+\mathrm{H}^{+}$ & $1.4 \times 10^{2} \mathrm{~s}^{-1}$ & $1.4 \times 10^{2} \mathrm{~s}^{-1}$ \\
\hline
\end{tabular}

${ }^{a}$ Aqueous phase reaction rate constants were obtained from Mack \& Bolton (1999).

${ }^{\mathrm{b}} \mathrm{QLL}$ rate reaction rate constants were quantified by including the 'volumetric' factor (Grannas et al. (2007), Takenaka et al. (1996)).

${ }^{\mathrm{c}} J_{\mathrm{NO}_{3}^{-}}$values were extrapolated from Qui et al. (2002) and King et al. (2005).

${ }^{\mathrm{d}} J_{\mathrm{NO}_{2}^{-}}$was extrapolated from Zuo \& Deng (1998).

${ }^{\mathrm{e}}$ Volumetric $\sim 8.20 \times 10^{-4}$ (Grannas et al. (2007); Takenaka et al. (1996)).

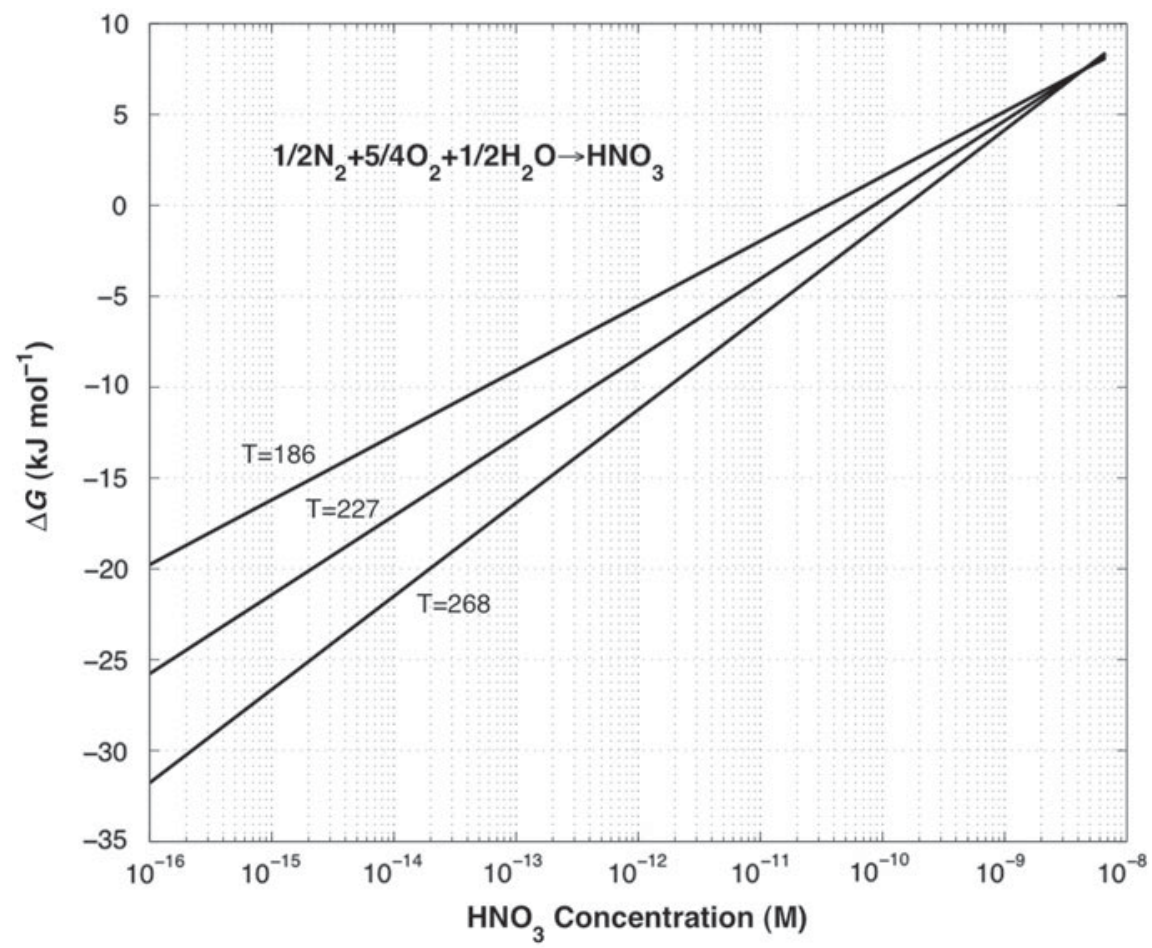

Fig. 2. The change in Gibbs free energy $(\Delta G)$ versus $\mathrm{HNO}_{3}$ concentration at 186, 227 and $268 \mathrm{~K}$.

\section{Photochemical reactions as a source of energy for nitrogen fixation}

Other forms of energy, such as UV radiation at the Martian surface can also produce fixed nitrogen species, such as $\mathrm{NO}(\mathrm{g})$ and $\mathrm{NO}_{2}(\mathrm{~g})$ via photolysis of $\mathrm{HNO}_{3}(\mathrm{~g})$ and $\mathrm{NO}_{3}{ }^{-}$(aq.), which has been investigated extensively in the lab (Dubowski et al. 2002; Boxe et al. 2003, 2005, 2006) and to a limited extent via multiphase modelling (Boxe \& Saiz-Lopez 2008). The gas phase concentration of $\mathrm{HNO}_{3}$ at the surface of Mars 


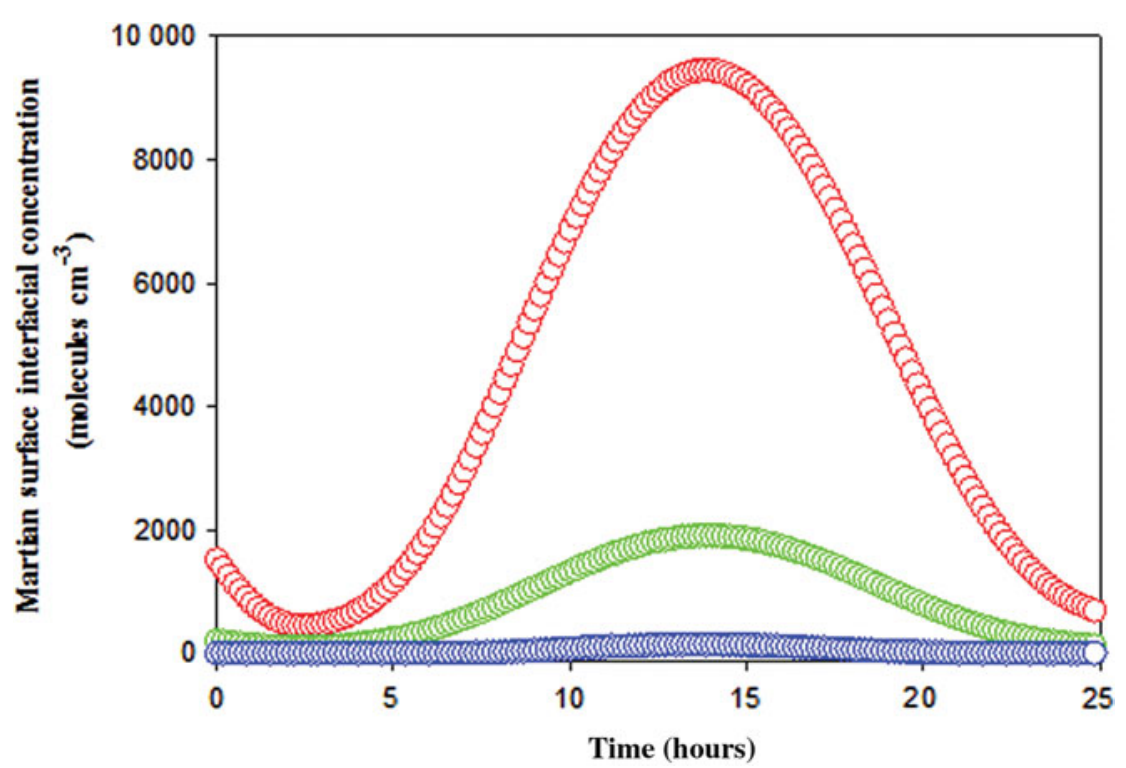

Fig. 3. Simulated evolution as a function of time (hours) and concentration molec $\mathrm{cm}^{3}$ of $\mathrm{NO}, \mathrm{NO}_{2}$ and $\mathrm{NO}_{2}{ }^{-}$during the heterogeneous photochemical processing of $\mathrm{NO}_{3}{ }^{-}$in thin liquid films on the Martian surface.

is $\sim 5 \times 10^{5}$ molec $\mathrm{cm}^{-3}$, which is equivalent to $8 \times 10^{-16} \mathrm{M}$ of $\mathrm{NO}_{3}{ }^{-}$. Since Boxe \& Saiz-Lopez (2008) calculated a $3 \times 10^{4}$ concentration enhancement from $9 \mu \mathrm{M} \mathrm{NO}_{3}{ }^{-}$in a $300-\mathrm{nm}-$ thick liquid layer, we calculate a $4.5 \times 10^{5}$ concentration effect for $8 \times 10^{-16} \mathrm{M}_{\text {of }} \mathrm{NO}_{3}{ }^{-}$absorbed in a 6-nm-thick interfacial film. We then initialize our model with $\left[\mathrm{NO}_{3}{ }^{-}\right]=4 \times 10^{-10} \mathrm{M}$. The actinic flux spectrum at the surface of Mars is from $200 \leqslant \lambda / \mathrm{nm} \leqslant 400$ (Yung \& Demore 1999) so the condensed phase model incorporates the predominant reactions representative of nitrate photochemistry in this wavelength region. The actinic flux spectrum for Mars' was also weighted to take into account $\mathrm{NO}_{3}{ }^{-}$absorption bands centred at $201 \mathrm{~nm}$ $\left(\varepsilon_{\max }=9500 \mathrm{M}^{-1} \mathrm{~cm}^{-1}\right)$ and $302 \mathrm{~nm}\left(\varepsilon_{\max }=7.14 \mathrm{M}^{-1} \mathrm{~cm}^{-1}\right)$ and $\mathrm{NO}_{2}{ }^{-}$absorption bands centred at $220 \mathrm{~nm}\left(\varepsilon_{\max }=\right.$ $\left.5800 \mathrm{M}^{-1} \mathrm{~cm}^{-1}\right), \quad 318 \mathrm{~nm} \quad\left(\varepsilon_{\max }=10.90 \mathrm{M}^{-1} \mathrm{~cm}^{-1}\right) \quad$ and $354 \mathrm{~nm}\left(\varepsilon_{\max }=22.90 \mathrm{M}^{-1} \mathrm{~cm}^{-1}\right)$. A volumetric factor was quantified by taking the average of the upper and lower limit reaction rate enhancement factors (unit-less numbers), obtained in the laboratory by Grannas et al. (2004) and Takenaka et al. (1996), 40 and $2.4 \times 10^{3}$, respectively, yielding $1.22 \times 10^{3}$. Therefore, the reaction rates are quantified by incorporating a volumetric factor, volumetric. Table 1 lists the major reactions pertaining to nitrate photochemistry, their condensed phase reaction rates and their interfacial reaction rates. Although we scale the secondary and tertiary non-photolytic reaction rates to give a thorough representation of nitrate photochemistry on the Martian surface, as shown by Boxe \& Saiz-Lopez (2008), the photolytic reactions dominate the evolution of $\mathrm{NO}, \mathrm{NO}_{2}$ and $\mathrm{NO}_{2}{ }^{-}$.

Figure 3 shows a diurnal profile of $\mathrm{NO}, \mathrm{NO}_{2}$ and $\mathrm{NO}_{2}{ }^{-}$ evolution in a 20 -nm-thick interfacial film due to heterogeneous photochemical processing of $\mathrm{NO}_{3}{ }^{-}$. $\mathrm{NO}, \mathrm{NO}_{2}{ }^{-}$and $\mathrm{NO}_{2}$ exhibit maximum concentrations of $1.3 \times 10^{2}, 2 \times 10^{3}$ and

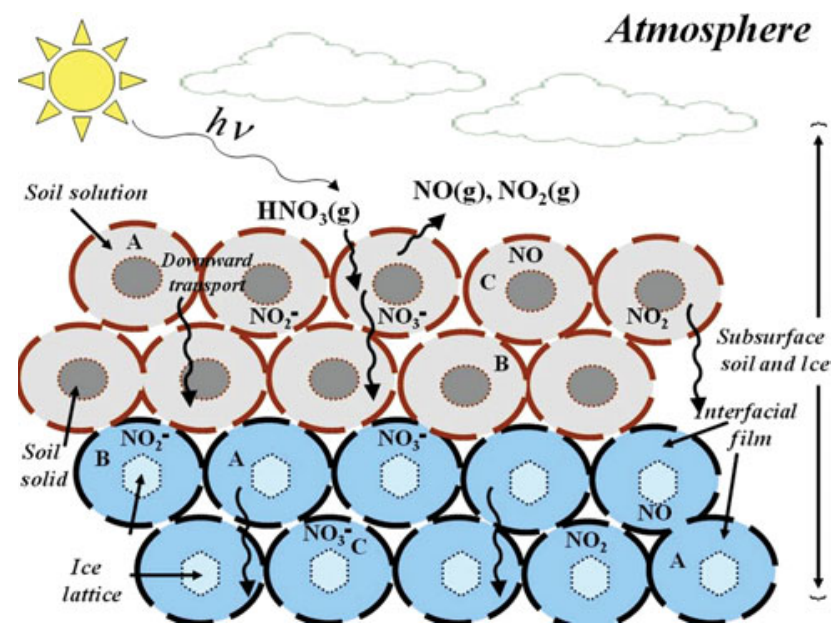

Fig. 4. Simplified schematic illustrating $\mathrm{HNO}_{3}$ (g) deposition and absorption in thin liquid films on the Martian surface (i.e. regolith (a) and ice (b)), followed by heterogeneous photochemical processing and transport of $\mathrm{NO}_{3}{ }^{-}, \mathrm{NO}_{2}{ }^{-}, \mathrm{NO}_{2}$ and $\mathrm{NO}$ to lower depths via mobility of thin liquid films to the Martian subsurface.

$9.4 \times 10^{3}$ molec $\mathrm{cm}^{3}$. Although the total integrated flux over $200-400 \mathrm{~nm}$ at the surface of Mars is comparable to the Earth's, the shorter wavelengths contribute a much greater proportion of this UV flux (e.g. $200 \leqslant \lambda / \mathrm{nm} \leqslant 315$ ). This is, the fact that $\mathrm{NO}_{2}$ is a primary photolytic product, due to its greater branching ratio (compared to $\mathrm{NO}_{2}{ }^{-}$) for photolytic production combined with the fact that $\mathrm{NO}_{3}{ }^{-}$centred at $201 \mathrm{~nm}$ has a greater absorption band, compared to the $\mathrm{NO}_{2}{ }^{-}$absorption band centred at $220 \mathrm{~nm}$ explains the greater production of $\mathrm{NO}_{2}$, compared to NO. In addition, the decrease in contribution of the actinic flux spectrum at $\lambda>315 \mathrm{~nm}$ also helps to explain the smaller amount of NO produced in the thin 
liquid film since nitrite's absorption bands are centred at 318 and $354 \mathrm{~nm}$. The concentration of $\mathrm{NO}_{3}{ }^{-}$in the interfacial film is constant due to the small quantum yield for $\mathrm{NO}_{2}$ and nitrite production and the fact that $\mathrm{NO}_{3}{ }^{-}$is replenished by atmospheric deposition of $\mathrm{HNO}_{3}$. This phenomenon implies that Martian surface is not a permanent sink for atmospheric nitrogen (Fig. 3).

\section{Downward transport of nitrogen $\left(\mathrm{HNO}_{3}(g)\right.$ and $\left.\mathrm{N}_{2}(g)\right)$}

Figure 4 also shows that there will be downward transport of nitrogen species to the Martian subsurface. In desert environments on Earth, water infiltration and leaching are minimal (Walvoord et al. 2003; Graham et al. 2008) so the downward transport of atmospheric nitrogen will be dominated by gasphase diffusion. Because the mean-free paths of $\mathrm{HNO}_{3}$ and $\mathrm{N}_{2}$ through the background atmosphere are greater than the typical pore size $(\sim 1 \mu \mathrm{m})$, molecular collisions with the walls of the pores dominate the transport of these molecules. This is known as Knudsen diffusion, for which we can take $D \sim\left(2 \varepsilon \mathbf{r}_{\mathrm{o}} / 3 \tau\right)(2 k T / \pi m)^{1 / 2}$, where $\mathbf{r}_{\mathrm{o}}$ is the pore size, $\varepsilon$ is the porosity, $\tau$ is the tortuosity and $m$ is the molecular mass of the diffusing component (Bullock et al. 1994; Harman \& McKay 1995). Consistent with diffusion models of Mars, we use $\mathbf{r}_{\mathrm{o}}=6 \times 10^{-4} \mathrm{~cm}, \varepsilon=0.5$ and $\tau \sim 5$ for depths less than $\sim 1 \mathrm{~km}$ (Squyres et al. 1992; Mellon \& Jakosky 1993; Bullock et al. 1994; Harman \& McKay 1995). At a mean surface temperature of $220 \mathrm{~K}$, we find that, above $1 \mathrm{~km}, D_{\mathrm{HNO}_{3}}$ $\sim 0.54 \mathrm{~cm}^{2} \mathrm{~s}^{-1}$ and $D_{\mathrm{N}_{2}} \sim 0.81 \mathrm{~cm}^{2} \mathrm{~s}^{-1}$. The maximum sink that could result from the Knudsen diffusion can be estimated by the rate of downward diffusion, $F$ (molecules $\mathrm{cm}^{-2} \mathrm{~s}^{-1}$ ), specified by $F=-D(\mathrm{~d} n / \mathrm{d} z)$, where $n$ is the number density of the diffusing component (molecules $\mathrm{cm}^{-3}$ ), $z$ is the depth (cm) with the surface set to $z=0, D$ is the diffusion coefficient $\left(\mathrm{cm}^{-2} \mathrm{~s}^{-1}\right)$ and $\mathrm{d} n / \mathrm{d} z$ is the density gradient (molecules $\mathrm{cm}^{-4}$ ). 1D photochemical simulations show that the number density of $\mathrm{HNO}_{3}$ and $\mathrm{N}_{2}$ at Mars' surface is $1.0 \times 10^{5}$ and $5.81 \times$ $10^{15}$ molecules $\mathrm{cm}^{-3}$, respectively. Thus a putative biotic layer at $10 \mathrm{~m}$ depth would produce $\mathrm{HNO}_{3}$ and $\mathrm{N}_{2}$ sinks of -54 and $-5 \times 10^{12}$ molecules $\mathrm{cm}^{-2} \mathrm{~s}^{-1}$, respectively, which is an ample supply of available nitrogen that can be efficiently transported to the subsurface to support a putative subsurface biosphere.

\section{Conclusions and implications}

Mars' total nitrogen atmospheric nitrogen content is $0.2 \mathrm{mbar}$ $\left(6.5 \times 10^{14} \mathrm{~kg}\right)$. The lower-limit nitrogen content in Martian biomass is $10^{10} \mathrm{~kg}$. These constraints are indicative of conditions of severe nitrogen deficiency. Over time, Mars' subsurface might have accumulated 2.8 mbar $\left(9 \times 10^{15} \mathrm{~kg}\right.$ of $\mathrm{N}$ ), which indicates that biological metabolism would not be inhibited at Mars' subsurface as suggested by the Klingler hypothesis (Klingler et al. 1989).

We show for the first time that the negative change in Gibbs free energy increases with decreasing $\mathrm{HNO}_{3}(\mathrm{~g})$ $\left(\mathrm{NO}_{3}{ }^{-}(\mathrm{aq})\right)$ in metastable thin liquid films that may exist at the surface of Mars, where additional reaction pathways are exergonic and may proceed spontaneously, thus providing an ample source of energy for nitrogen fixation on Mars.

Condensed phase simulations show that photochemically produced fixed nitrogen species are not only released from the Martian surface to the gas-phase, but more importantly, transported to lower depths from the Martian surface in transient thin liquid films. For example, a putative biotic layer at $10 \mathrm{~m}$ depth would produce $\mathrm{HNO}_{3}$ and $\mathrm{N}_{2}$ sinks of -54 and $-5 \times 10^{12}$ molecules $\mathrm{cm}^{-2} \mathrm{~s}^{-1}$, respectively. This is an ample supply of available nitrogen that can be efficiently transported to the subsurface. The downward transport and release to the atmosphere of photochemically produced fixed nitrogen species suggests the existence of a transient nitrogen cycle on Mars.

\section{References}

Bogard, D.D., Clayton, R.N., Marti, K., Owen, T. \& Turner, G. (2001). Space. Sci. Rev. 96, 425-458.

Boxe, C.S. \& Saiz-Lopez, A. (2008). Atmos. Chem. Phys. 8, 4855-4864.

Boxe, C.S. et al. (2003). J. Phys. Chem. A 107, 11409-11413.

Boxe, C.S. et al. (2005). J. Phys. Chem. A 109, 8520-8525.

Boxe, C.S. et al. (2006). J. Phys. Chem. A 110, 7613-7616.

Boxe, C.S. et al. (2011). Int. J. Astrobiol. submitted.

Bullock, M., Stoker, C., McKay, C. \& Zent, A. (1994). Icarus 107, 142-154.

Capone, D.G., Popa, R., Flood, B. \& Nealson, K. (2006). Science 312, 708-709.

Dubowski, Y., Colussi, A.J., Boxe, C.S. \& Hoffmann, M.R. (2002). J. Phys. Chem. A 106, 6967-6971.

Ducluzeau, A.-L., Lis, R.V., Duval, S., Schoepp-Cothenet, B., Russell, M. \& Nitschke, W. (2009). Trends Biochem. Sci. 34, 9-15.

Field, C.B., Behrenfeld, M.J., Randerson, J.T. \& Falkowski, P. (1998). Science 281, 237-240.

Fox, J.L. \& Delgarno, A. (1983). J. Geophys. Res. 88(A11), 9027-9032.

Graham, R.C., Hirmas, D.R., Wood, Y.A. \& Amrhein, C. (2008). Geology 36, 259-262.

Grannas, A.M., Bausch, A.R. \& Mahanna, K.M. (2007). J. Phys. Chem. A 111, 11043-11049.

Grannas, A.M., Shepson, P.B. \& Filley, T.R. (2004). Global Biogeochem. Cycles 18, doi: 10.1029/2003GB002133, GB1006(1-10).

Harman, H. \& McKay, C. (1995). Planet. Space Sci. 43, 123-128.

Huber, H. et al. (2002). Nature 417, 63-67.

Jakosky, B.M. \& Phillips, R.L. (2001). Nature 412, 237-244.

King, M.D., France, J.L., Fisher, F.N. \& Beine, H.J. (2005). J. Photochem. Photobiol. A 176, 39-49.

Klingler, J.M., Mancinelli, R.L. \& White, M.R. (1989). Adv. Space Res. 9, 173-176.

Lide, David R. (eds) (2006). CRC Handbook of Chemistry and Physics, 89th edn (Internet Version 2009). CRC Press/Taylor and Francis, Boca Raton, FL.

Mack, J. \& Bolton, J.R. (1999). J. Photochem. and Photobiol. A 128, 1-13. Mancinelli, R.L. \& Banin, A. (2003). Int. J. Astrobiol. 2, 217-225.

McElroy, M.B., Kong, T.Y. \& Yung, Y.L. (1977). J. Geophys. Res. 82, 4379-4388.

McKay, C.P. \& Stoker, C.R. (1989). Rev. Geophys. 27, 189-214.

Mellon, M. \& Jakosky, B. (1993). J. Geophys. Res. 98, 3343-3364.

Price, P.B. (2007). Microbiol. Ecol. 59, 217-231.

Qiu, R., Green, S.A., Honrath, R.E., Peterson, M.C., Lu, Y.\& Dziobak, M. (2002). Atmos. Environ. 36, 2563-2571.

Rubio, L.M. \& Ludden, P.W. (2005). J. Bacteriol. 187, 405-414. 
Squyres, S.W., Clifford, S.M., Kuzmin, R.O., Zimbelman, J.R. \& Costard, F.M. (1992). In Mars, ed. Kieffer, H., Jakosky, B., Snyder, C. \& Matthews, M., pp. 523-554. University of Arizona Press, Tuscon, AZ. Summers, D.P. \& Khare, B. (2007). Astrobiology 7, 333, doi: 10.1089/ ast.2006.0032.

Takenaka, N. et al. (1996). J. Phys. Chem. 100, 13874-13884.

Walvoord, M.A. et al. (2003). Science 302, 1021-1024.
Weiss, B.P., Yung, Y.L. \& Nealson, K.H. (2000). Proc. Natl Acad. Sci. USA 97, 1395-1399.

Yung, Y.L. \& Demore, W.B. (1999). Photochemistry of Planetary Atmospheres, Oxford University Press, Oxford.

Zehr, J.P., Jenkins, B.D., Short, M.D. \& Steward, G.F. (2005). Environ. Microb. 5, 539-554.

Zuo, Y. \& Deng, Y. (1998). Chemosphere 36, 181-188. 